\title{
A new phytophagous Bracon Fabricius (Hymenoptera, Braconidae) associated with Protium ovatum Engl. (Burseraceae) fruits from Brazilian savannah
}

\author{
NELSON WANDERLEY PERIOTO ${ }^{1,2}$, ROGÉRIA INÊS ROSA LARA ${ }^{1}$, CLEIDSON SOARES FERREIRA ${ }^{2}$, \\ DANIELL RODRIGO RODRIGUES FERNANDES ${ }^{2}$, ELIZABETH DO CARMO PEDROSO ${ }^{2}$, \\ HAROLDO XAVIER LINHARES VOLPE ${ }^{2}$, JULIANA NAIS ${ }^{2}$, LILIAN ROBERTA BATISTA CORREA ${ }^{2} \&$ SIL- \\ VIO ROGÉRIO VIEL ${ }^{2}$ \\ ${ }^{1}$ Agência Paulista de Tecnologia dos Agronegócios (APTA), Pólo Centro Leste, Ribeirão Preto, Av. Bandeirantes 2419, 14030-670, \\ Ribeirão Preto, SP, Brazil.E-mail: nperioto2@gmail.com \\ ${ }^{2}$ Universidade Estadual Paulista “Júlio de Mesquita Filho” (UNESP), Faculdade de Ciências Agrárias e Veterinárias, Programa de \\ Pós-graduação em Agronomia (Entomologia Agrícola), Via de Acesso Prof. Paulo Donato Castellane s/n, 14888-900, Jaboticabal, \\ SP, Brazil
}

\begin{abstract}
Bracon zuleideae Perioto \& Lara sp. nov. (Hymenoptera, Braconidae), a new species of phytophagous braconid associated with fruits of Protium ovatum Engl. (Burseraceae) is described and illustrated.
\end{abstract}

Key words: Braconinae, Brazil, Neotropical, phytophagy, seed predation, taxonomy

\section{Resumo}

Bracon zuleideae Perioto \& Lara sp. nov. (Hymenoptera, Braconidae), uma nova espécie de braconídeo fitófago associada a frutos de Protium ovatum Engl. (Burseraceae) é descrita e ilustrada.

Palavras chave: Braconinae, Brasil, Neotropical, fitofagia, predação de sementes, taxonomia

\section{Introduction}

Here we describe Bracon zuleideae Perioto \& Lara sp. nov., a parasitoid of seeds which is phytophagous within fruits of Protium ovatum Engl. (Burseraceae). This is the second known phytophagous species of this genus in seeds of Protium: the first, Bracon phytophagous Quicke, 2005, was obtained from fruits of P. tovarense Pittier (Burseraceae) in Venezuela (Flores et al., 2005). "Parasitoids of seeds" refers to Hymenoptera in which a single larva develops on or inside a single seed (Hanson, 2006).

Reports of braconids with phytophagous immature stages are relatively recent in the literature. Macêdo and Monteiro (1989) published the first report of phytophagy in Braconidae and Marsh (1991) described Allorhogas dyspistus, the first phytophagous braconid, which causes galls in Fabaceae.

Several species of Allorhogas (Doryctinae) act as primary gall formers (Marsh, 2002; Wharton and Hanson, 2005; Chavarria et al., 2009; Centrella and Shaw, 2010). In Doryctinae, phytophagy was also reported in Monitoriella (Infante et al. 1995) and probably occurs in Labania (Wharton and Hanson, 2005), Mononeuron (Chavarría et al., 2009), and Psenobolus (Ramírez and Marsh, 1996). All of these insects have a neotropical distribution. Outside of the Neotropics phytophagy in braconids has been reported in Mesostoa (Mesostoinae) from Australia (Austin and Dangerfield, 1998) and is suspected in Ficobracon (Braconinae) from Papua New Guinea (Achterberg and Weiblen, 2000). 